\title{
TEKNIK PENGAMBILAN PERIFITON PADA RANTING TUMBUHAN DI SEKITAR DESA PEMULUTAN MARIANA, SUMATERA SELATAN
}

\author{
Mirna Dwirastina \\ Teknisi Litkayasa pada Balai Riset Perikanan Perairan Umum, Mariana-Palembang \\ Teregristasi I tanggal: 29 April 2007; Diterima setelah perbaikan tanggal: 10 Mei 2007; \\ Disetujui terbit tanggal: 6 Desember 2007
}

\section{PENDAHULUAN}

Berdasarkan pada topografi, sungai terletak di dataran tinggi dan dataran rendah. Bagian utama perairan umum di Sumatera Selatan adalah Sungai Musi (Anonimus, 1987). Menurut Samuel et al. (2002), Sungai Musi terbagi 3 wilayah, yaitu hulu, tengah, dan hilir.

Pengambilan contoh dilakukan pada daerah Desa Pemulutan Kecamatan Mariana yang termasuk perairan bagian hilir Sungai Musi. Lokasi tersebut bertempat dekat Pulau Salah Nama yang banyak tanaman air serta dekat dengan lokasi pabrik minyak.

Di perairan terdapat organisme dan biota-biota yang sangat mendukung kelangsungan ekosistem perairan tersebut. Organisme perairan dapat digolongkan sesuai bentuk dan kebiasaan hidup, wilayah atau sub habitat. Berdasarkan pada kebiasaan hidup, organisme digolongkan antara lain bentos, perifiton, plankton, nekton, dan neuston.

Perifiton adalah kelompok berbagai organisme yang tumbuh atau hidup pada permukaan bebas dari benda yang melayang dalam air seperti tanaman, kayu dan batu (Michael, 1994). Perifiton merupakan produsen primer yang penting dalam arus yang mengalir cepat, di mana plankton tak dapat hidup.

Tujuan penulisan makalah ini adalah untuk memberikan informasi cara pengambilan contoh perifiton, dan jenis-jenis perifiton yang ada di Desa Pemulutan Mariana, Sumatera Selatan.

\section{POKOK BAHASAN}

Pengamatan perifiton dilakukan di perairan sekitar Desa Pemulutan Kecamatan Mariana Palembang. Metode yang digunakan adalah dengan cara pengambilan contoh secara langsung di lokasi, pemeriksaan dan perhitungan dilakukan di laboratorium.

\section{Alat dan Bahan}

Alat-alat yang digunakan dalam pengambilan contoh perifiton adalah pisau, mistar atau jangka sorong, kantong plastik, karet, pipet, cawan petri, sikat gigi, gelas ukur, pinset, kertas, dan pena. Sedangkan bahan untuk mengawetkan contoh adalah larutan lugol.

Cara kerja pengamatan perifiton dilakukan dengan 2 tahap, yaitu di lapangan dan laboratorium.

Cara kerja di lapangan sebagai berikut:

1. Alat-alat disiapkan berupa pisau, kantong plastik, karet, pipet, lugol, mistar, atau jangka sorong.

2. Ranting tanaman hidup yang terdapat di perairan tersebut dipotong kira-kira $10-20 \mathrm{~cm}$.

3. Potongan tersebut dimasukkan dalam kantong plastik dan diisi air kira-kira $350 \mathrm{ml}$ yang berasal dari lokasi tersebut.

4. Contoh dalam kantong plastik diberi larutan lugol sebanyak 5 tetes, kemudian diberi label yang berisi tanggal dan tempat.

5. Kantong plastik diikat kuat dengan karet agar contoh tidak rusak dan bocor sebelum diperiksa.

Cara kerja di laboratorium sebagai berikut:

1. Kantong plastik dibuka, contoh ranting diambil diletakkan dalam cawan petri.

2. Kemudian ukur panjang ranting dan diameter ranting dengan jangka sorong sambil dipegang dengan menggunakan pinset.

3. Kemudian ranting disikat menurun ke bawah (Gambar 1).

4. Hasil penyikatan ranting dimasukkan dalam gelas ukur beserta air contoh pada kantong plastik. Catat volume air contoh.

5. Homogenkan dengan cara mengaduk atau mengocok air tersebut dan dituangkan ke botol sekitar $25 \mathrm{ml}$.

6. Contoh perifiton diperiksa menggunakan mikroskop.

\section{Hasil Pemeriksaan}

Rumus luas pada ranting: $1 / 2 \pi r^{2} x t$

Panjang $=13,1 \mathrm{~cm}$; diameter $=0,3 \mathrm{~cm}$; air contoh $=350 \mathrm{cc}$, contoh yang diperiksa $0,5 \mathrm{ml}$.

Pada pengamatan perifiton, jumlah organisme di atas dihitung berdasarkan pada jumlah individu per satuan luas. Hasil perhitungan perifiton tercantum pada Tabel 1. 


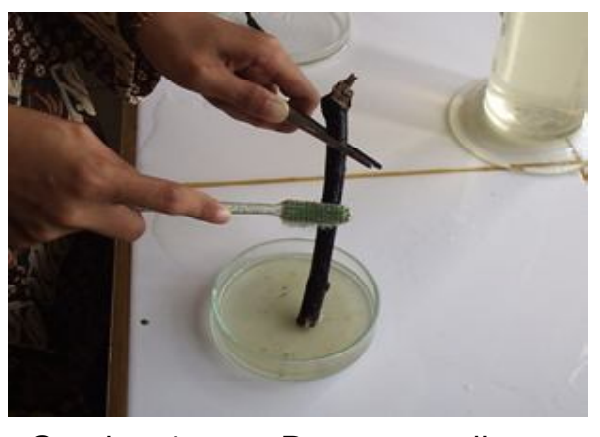

Gambar 1. Proses penyikatan.

Tabel 1. Persentase jenis-jenis perifiton hasil pengamatan

\begin{tabular}{clcc}
\hline No. & \multicolumn{1}{c}{ Nama genus } & Jumlah individu per $\mathbf{c m}^{\mathbf{2}}$ & Persentase (\%) \\
\hline 1. & Synedra & 194,5 & 7,14 \\
2. & Ulothrix & 680,7 & 25,00 \\
3. & Navicula & 291,7 & 10,71 \\
4. & Closterium & 324,1 & 11,90 \\
5. & Mougeotia & 421,3 & 15,47 \\
6. & Oscillatoria & 129,6 & 4,76 \\
7. & Docidium & 162,07 & 5,95 \\
8. & Diatoma & 356,6 & 13,10 \\
9. & Brachionus & 32,41 & 1,19 \\
10. & Scenedesmus & 32,41 & 1,19 \\
11. & Zygnema & 97,24 & 3,57 \\
\hline & Total & $\mathbf{2 . 7 2 2 , 6 3}$ & \\
\hline
\end{tabular}

Pada pemeriksaan di atas terdapat jenis-jenis perifiton yang meliputi fitoplankton dan zooplankton. Jenis-jenis fitoplankton yang ditemukan Synedra, Ulothrix, Navicula, Closterium, Mougeotia, Oscillatoria, Docidium, Diatoma, Scenedesmus, Zygnema, dan zooplankton yang ditemukan genus Brachionus.

\section{KESIMPULAN}

1. Pengambilan perifiton pada ranting yaitu dengan cara memotong ranting tersebut yang telah ditentukan ukuran sehingga dapat diketahui luasan dan ditentukan kepadatan.

2. Jenis-jenis perifiton yang ditemukan dalam bentuk fitoplankton ada 10 jenis dan zooplankton 1 jenis yaitu Brachionus.

3. Dari hasil pengamatan jenis perifiton yang dominan adalah Ulothrix $25 \%$ dari 11 jenis plankton yang ditemukan.

\section{DAFTAR PUSTAKA}

Anonimus. 1987. Kapupaten Musi Banyuasin Dalam Angka. Badan Pemerintah Daerah Tingkat II. Kabupaten Musi Banyuasin, Sumatera Selatan. Sekayu. Sumatera Selatan. 337 pp.

Michael, P. 1994. Metode Ekologi di Lapangan dan Analisis Laboratorium. Universitas Indonesia. Jakarta.

Samuel, S. Adjie, \& Subagja. 2002. Inventarisasi dan distribusi biota serta karakteristik habitat perairan Sungai Musi. Laporan Teknis Penelitian T.A. 2003. Proyek Riset Perikanan Perairan Umum Palembang. Balai Riset Perikanan Perairan Umum. Palembang. 